\title{
MOTIVASI KERJA DAN KINERJA GURU MADRASAH SERTA IMPLIKASINYA BAGI MANAJEMEN PENDIDIKAN ISLAM
}

\author{
Ahmad Hudlori Ihsan \\ Universitas Islam Negeri Sunan Gunung Djati Bandung \\ ihsanahmad751@gamil.com
}

\section{Supiana}

Universitas Islam Negeri Sunan Gunung Djati Bandung supiana@uinsgd.ac.id

\author{
Neng Gustini \\ Universitas Islam Negeri Sunan Gunung Djati Bandung \\ neng.gustini@uinsgd.ac.id
}

\begin{abstract}
ABSTRAK
Pendidikan adalah hal yang sangat penting. Salah satu yang mendasari bahwa urgensi dari pendidikan adalah pengembangan sumber daya manusia agar mempunyai mutu pendidikan yang tinggi. Agar mampu dalam menembangkan sumber daya manusia dibutuhkan motivasi yang tinggi, sehingga diharapkan menghasilkan kinerja yang optimal. Namun permasalahan yang terjadi, terkadang motivasi berubah-ubah sesuai dengan keadaan dari setiap individunya, kinerja yang belum maksimal, seperti ada beberapa guru yang tidak menggunakan media dalam pembelajaran, kurangnya dalam melengkapi administrasi kelas dan masih ada yang belum menguasai teknologi. Itulah yang menjadi dasar penelitian ini agar mampu menjabarkan permasalahan yang terjadi dan berkontribusi dalam mengembangkan sumber daya manusia. Penelitian ini termasuk dalam jenis penelitian kuantitatif dengan metode deskriptif korelasi. Dalam pengambilan sempel peneliti menggunakan teknik sampling total. Peneliti menyebarkan kuesioner sebanyak 32 sampel, dengan menggunakan kuesioner model skala likert sebagai data primer yang disebar melalui online dengan menggunakan google form. Dari hasil penelitian diketahui bahwa terdapat hubungan antara motivasi kerja guru dengan kinerja guru di MTs Mohamad Toha Kota Cimahi dengan nilai 0,888 yang artinya tingkat kekuatan hubungannya sangat kuat. Dengan demikian dapat disimpulkan bahwa $\mathrm{Ha}$ diterima, dan terdapat hubungan yang positif serta signifikan antara motivasi kerja dengan kinerja guru di MTs Mohamad Toha Kota Cimahi.
\end{abstract}

Kata kunci: motivasi, kerja, kinerja, guru 


\section{ABSTRACT}

Education is a really important matter. One of the underlying reasons that the urgency of education is the development of human resources in order to have a high quality of education. In order to be able to develop human resources, high motivation is needed, so that it is expected to produce optimal performance. However, the problems that occur are, sometimes motivation changes according to the circumstances of each individual, performance is not maximized, such as some teachers who do not use media in learning, lack of complete classroom administration and there are still those who have not mastered technology. That is the basis of this research in order to be able to describe the problems that occur and contribute to developing human resources. This research is included in the type of quantitative research with descriptive correlation method. In taking the sample, the researcher used a total sampling technique. The researcher distributed a questionnaire of 32 samples, using a Likert scale model questionnaire as primary data which was distributed online using google form. From the results of the study, it is known that there is a relationship between teacher work motivation and teacher performance at MTs Mohamad Toha Cimahi with a value of 0.888 which means the level of strength of the relationship is very strong. Thus it can be concluded that $\mathrm{Ha}$ is accepted, and there is a positive and significant relationship between work motivation and teacher performance at MTs Mohamad Toha Cimahi.

Key words: motivation, work, performance, teacher

\section{PENDAHULUAN}

Pendidikan adalah hal yang sangat penting, agar mampu bersaing dengan belahan dunia manapun. Bangsa Indonesia mempunyai tantangan agar dapat meningkatkan mutu sumber daya manusia yang berpendidikan. Salah satu yang mendasari bahwa urgensi dari pendidikan adalah pengembangan sumber daya manusia agar mempunyai mutu pendidikan yang tinggi. Sumber daya manusia yang mempunyai mutu yang tinggi serta profesional dalam bidangnya, agar dapat mencerminkan kualitas dan kuantitas serta kemajuan suatu bangsa dan negara. Sumber daya yang berkualitas dan profesional mampu menciptakan pendidikan yang berkualitas (Munirah, 2015).

Komponen-komponen dalam pendidikan nasional, antara lain lingkungan, sarana dan prasarana, sumber daya, dan masyarakat. Komponen tersebut bekerjasama saling terkait dan mendukung dalam mencapai tujuan pendidikan (Saoetarno, 2004). Sebagai salah satu sumber daya manusia yang ada dalam pendidikan, seorang kepala sekolah harus menekankan pentingnya memimpin sekolah agar guru merasa betah berada dalam tim kerja yang efektif, merasa senang dengan pekerjaannya, serta merasa meraih sesuatu yang berguna dalam pekerjaannya.

Kepala sekolah termasuk dalam komponen-komponen pendidikan yang mempunyai salah satu tugas untuk memberikan motivasi kepada para guru. Mediator yang dapat membangkitkan inspirasi, motivasi, dukungan dan bimbingan adalah kepala sekolah, sehingga dapat memberikan arahan untuk memunculkan potensi yang maksimum pada seorang guru dan tercapainya peningkatan kualitas sekolah (Sonedi et al., 2018). Guru adalah tenaga pengajar 
yang profesional dalam bidangnya, untuk meningkatkan mutu pendidikan. Bagian dari sumber daya yang ada dalam lembaga kependidikan merupakan kualitas dari seorang tenaga pendidik (Sahertian, 2010). Selain sebagai pendidik, guru juga merupakan seorang manajer. Di dalam kelas, guru adalah administrator, guru harus mampu dalam melaksanakan kegiatan manajemen (Daryanto \& Farid, 2013, p. 12).

Para pegawai (guru) memiliki motivasi yang tinggi agar bekerja dengan sungguh-sungguh (Ardiana, 2017). Jika motivasi yang positif dimiliki oleh seorang guru, maka ia akan memperlihatkan minatnya, mempunyai perhatian yang cukup, dan berkeinginan ikut serta dalam penugasan-penugasan atau kegiatan-kegiatan (Mulyasa, 2004, p. 120). Selain sebagai pendidik, guru juga merupakan seorang manajer. Di dalam kelas, guru adalah administrator, guru harus mampu dalam melaksanakan kegiatan manajemen (Daryanto \& Farid, 2013, p. 12).

Motivasi dalam bidang manajemen pendidikan Islam merupakan suatu bimbingan atau arahan dalam upaya mendorong kepada seluruh SDM dari personil yang berada dalam suatu lembaga agar dapat menjalankan tugastugasnya dengan penuh kesadaran yang tinggi (Samsirin, 2016). Motivasi dalam Islam adalah seorang muslim bukan hanya harta dan jabatan, tetapi pahala dari Allah. Tidak sepantasnya seorang muslim memiliki etos kerja yang lemah (Hidayat \& Wijaya, 2017, p. 172). Urgensi motivasi kerja harus dipahami untuk meningkatkan performansi kerja guru sehingga urgensinya dapat disadari oleh guru tersebut (Putra \& Wikansari, 2017). Esensi motivasi nonfinansial yaitu pemberian pujian yang memicu dorongan dalam bekerja, pemberian penghargaan, pendekatan dengan manusiawi dan lain sebagainya.

Kinerja guru adalah keberhasilan guru dalam menjalankan tugas-tugas pembelajaran yang diembannya. Pandangan Islam mengenai kinerja (hasil kerja) segala sesuatu yang telah diperbuat oleh seseorang yang sesuai dengan standar yang ada (Amaliah et al., 2013). Teori lain juga mengemukakan bahwa kinerja adalah hasil yang dicapai oleh guru sebagai tenaga pendidik secara kualitas dan kuantitas dalam mempertanggungjawabkan pekerjaan yang diberikan kepadanya (Mangkunegara, 2019, p. 9). Urgensi kinerja guru adalah meningkatkan dan menumbuhkan kinerja guru agar dapat mensukseskan instansi atau kepentingan dari pegawai itu sendiri (Tentama, 2015).

Peneliti memilih meneliti di MTs Mohamad Toha Kota Cimahi karena memiliki keunikan dibandingkan dengan madrasah lainnya. MTs Mohamad Toha Kota Cimahi memiliki pembelajaran yang menggunakan teknologi informatika. Walapun di bawah jajaran madrasah, MTs Mohamad Toha Kota Cimahi unggul dalam teknologi meskipun masih termasuk kategori sekolah baru. MTs Mohamad Toha Kota Cimahi menjadi pelopor untuk menggunakan teknologi informatika dalam melaksanakan pembelajaran, namun tidak melupakan iman dan takwa sesuai dengan visinya.

Berdasarkan hasil studi pendahuluan di MTs Mohamad Toha Kota Cimahi didapatkan informasi bahwa fenomena yang terjadi disana adalah motivasi guru terkadang berubah-ubah sesuai dengan keadaan dari setiap individunya, kinerja yang belum maksimal, seperti ada beberapa guru yang tidak menggunakan media dalam pembelajaran, kurangnya dalam melengkapi administrasi kelas dan masih ada yang belum menguasai teknologi. 


\section{METODE}

Metode penelitian yang digunakan dalam penelitian ini adalah metode kuantitatif. Metode kuantitatif digunakan untuk penelitian yang berlandaskan pada filsafat positivisme, digunakan untuk meneliti pada populasi atau sampel tertentu, pengumpulan data menggunakan instrumen penelitian, analisis data bersifat kuantitatif/statistik, dengan tujuan untuk menggambarkan dan menguji hipotesis yang telah ditetapkan. Selanjutnya penelitian yang digunakan adalah penelitian deskriptif dengan jenis penelitian survei.

Penelitian deskriptif adalah bentuk analisis data penelitian yang digunakan untuk menguji generalisasi hasil penelitian berdasarkan satu sampel (Siregar, 2015, p. 126). Dan jenis penelitian survei adalah penelitian yang dilakukan untuk menggambarkan populasi besar ataupun kecil, tetapi data yang dipelajari adalah data dari sampel yang di ambil dari populasi tersebut, untuk menemukan kejadian kejadian relatif, distribusi, dan hubungan antar variabel sosiologis maupun psikologis (Sugiyono, 2017).

\section{HASIL DAN PEMBAHASAN Temuan Penelitian}

Validitas adalah suatu alat ukur yang digunakan untuk melihat sejauh mana alat ukur mampu untuk menjadi alat ukur apa yang diukur (Siregar, 2015, p. 46). Setelah membuat kuesioner (instrument penelitian) langkah selanjutnya menguji apakah kuesioner yang dibuat tersebut valid atau tidak. Dari hasil uji validitas diketahui bahwa variabel motivasi kerja $(X)$ yang berjumlah 15 item pernyataan positif, dinyatakan valid sebanyak 15 . Dan variabel kinerja guru ( $\mathrm{Y}$ ) yang terdiri dari 19 item pernyataan, semua pernyataannya dinyatakan valid.

Reliabilitas adalah alat ukur yang digunakan untuk mengukur sejauh mana pengukuran tetap konsisten apabila pengukuran dilakukan dua kali maka dengan gejala yang sama dan alat ukur yang digunakan sama (Siregar, 2015, p. 55). Dari hasil perhitungan, diketahui bahwa seluruh item yang digunakan pada variabel motivasi kerja $(X)$ dinyatakan reliabel, karena hasil uji dengan nilai alpha $0,783>r^{\text {tabel }} 0,06$. Dan untuk seluruh item yang digunakan pada variabel kinerja guru (Y) dinyatakan realibel, karena hasil uji dengan nilai alpha 0,849> rabel 0,06.

Statistik deskriptif merupakan bentuk analisis data yang digunakan untuk menguji generalisasi hasil penelitian yang berdasarkan pada satu sampel (Siregar, 2015, p. 126). Statistik deskriptif seperti mean, median, modus, presentil, desil, quartile, dalam bentuk analisis angka maupun gambar atau diagram. Dalam analisis deskriptif data diolah pervariabel. Untuk mengetahui seberapa besar hubungan motivsi kerja dengan kinerja guru, maka peneliti melakukan pengukuran dengan menggunakan kuisioner.

Berdasarkan hasil pengolahan data, menunjukkan bahwa keseluruhan jawaban responden pada variabel motivasi, dengan persentase sebesar $72,58 \%$, maka dikategorikan dalam persentase yang tinggi. Sedangkan untuk keseluruhan jawaban responden pada variabel kinerja guru, dengan persentase sebesar $74,21 \%$, maka dikategorikan dalam persentase yang tinggi. Sehingga 
baik variable motivasi guru maupun variable kinerja guru keduanya termasuk kategori yang tinggi.

Teknik penelitian korelasi yang digunakan adalah korelasi Product Moment. Teknik korelasi ini digunakan untuk mencari hubungan dan membuktikan hipotesis hubungan dua variabel bila data kedua variabel berbentuk interval atau rasio, dan sumber data dari dua variabel atau lebih tersebut adalah sama (Sugiyono, 2017, p. 228).

Uji normalitas bertujuan untuk menguji apakah dalam model regresi, variabel pengganggu atau residual memiliki distribusi normal. Seperti diketahui bahwa uji t dan uji $\mathrm{F}$ mengasumsikan bahwa nilai residual mengikuti distribusi normal. Kalau asumsi ini dilanggar maka uji statistik menjadi tidak valid untuk jumlah sampel kecil. Alat analisis yang digunakan dalam penelitian ini adalah uji Kolmogorov-Smirnov.

Berdasarkan perhitungan statistic diperoleh nilai Asymp.sig pada variabel motivasi kerja sebesar 0,065 dan pada variabel kinerja guru sebesar 0,097. Dikarenakan nilai Asymp.sig > 0,05, maka dapat disimpulkan bahwa sebaran datanya berdistribusi normal.

Pada uji linearitas data bertujuan untuk mengetahui hubungan antar dua variabel apakah ada linier atau tidak (Sudjana, 2011, p. 202). Pada pengujian linearitas data menggunakan SPSS, kemudian hasil yang diperoleh dari uji linearitas data disajikan berupa grafik yang bisa disebut scatter plot. Berdasarkan gambar scatter plot, diketahui output menunjukkan bahwa hubungan antara variabel motivasi kerja $(\mathrm{X})$ dan variabel kinerja guru $(\mathrm{Y})$, terlihat bahwa titik-titik plot data membentuk garis lurus dari bawah kiri naik ke atas kanan. Hal ini menunjukkan bahwa antara variabel $X$ dan variabel $Y$ memiliki hubungan yang linier. Karena berbentuk linear, maka analisis korelasi product moment dapat dilanjutkan.

Untuk menguji ada tidaknya hubungan antara variabel motivasi dengan kinerja, maka penulis melakukan analisis korelasi dengan menggunakan program SPSS. Berdasarkan perhitungan SPSS tersebut diketahui bahwa terdapat hubungan antara variabel motivasi dengan kinerja guru sebesar 0,888 dan nilai signifikansi sebesar $0,000<0,05$. Maka korelasi diantara variabel motivasi dengan kinerja guru positif dan signifikan, serta berada pada korelasi sangat kuat.

Koefisien determinasi merupakan koefisien penentu, karena varian variabel dependen dapat dijelaskan melalui varian yang terjadi pada variabel independent (Sugiyono, 2017, p. 213). Dengan demikian, maka diperoleh nilai Koefisien Determinasi sebesar $78,85 \%$ yang menunjukkan arti bahwa variabel motivasi kerja memberikan kontribusi terhadap variabel kinerja guru sebesar $78,85 \%$. Sedangkan sisanya sebesar $21,15 \%$ dipengaruhi oleh faktor lain yang diabaikan penulis.

Penelitian ini bertujuan untuk mengetahui hubungan motivasi kerja dengan kinerja guru di MTs Mohamad Toha Kota Cimahi. Berdasarkan data penelitian yang dianalisis, ringkasan hasil penelitian dapat dilihat pada pembahasan berikut ini. Motivasi kerja guru di MTs Mohamad Toha Kota Cimahi, berdasarkan hasil pengolahan data, menunjukkan bahwa keseluruhan jawaban responden pada variabel motivasi, dengan persentase sebesar $72,58 \%$, maka dikategorikan dalam persentase yang tinggi. Persentasi tersebut didapat dengan 
rumus skor total yaitu sebesar 1742 dibagi skor ideal yaitu sebesar 2400 dan dikalikan 100 sehingga mendapatkan nilai persentase sebesar 72,58\% yang masuk dalam kategori tinggi. Dengan demikian bahwa motivasi kerja guru MTs Mohamad Toha Kota Cimahi termasuk dalam kualifikasi tinggi. Sesuai pendapat Mulyasa yang menyatakan bahwa para pegawai (guru) mempunyai motivasi yang tinggi agar bekerja dengan sungguh-sungguh. Sehingga semakin tinggi motivasi guru semakin tinggi kinerja yang dihasilkan. Namun masih ada kendala yang terjadi, yaitu sebagian besar guru menjawab bahwa fasilitas-fasilitas penunjang guru dalam memberikan pembelajaran masih ada yang kurang (Mulyasa, 2004, p. 120).

Kinerja guru di MTs Mohamad Toha Kota Cimahi, berdasarkan hasil pengolahan data, menunjukkan bahwa keseluruhan jawaban responden pada variabel kinerja guru, dengan persentase sebesar $74,21 \%$, maka dikategorikan dalam persentase yang tinggi. Persentasi tersebut didapat dengan rumus skor total yaitu sebesar 2256 dibagi skor ideal yaitu sebesar 3040 dan dikalikan 100 sehingga mendapatkan nilai persentase sebesar $74,21 \%$ yang masuk dalam kategori tinggi. Dengan demikian bahwa kinerja guru MTs Mohamad Toha Kota Cimahi termasuk dalam kualifikasi tinggi. Hal ini berbeda dengan penelitian (Yulia, 2017) yang menyatakan bahwa identifikasi kategori kecenderungan variabel kinerja guru, menunjukkan bahwa kecenderungan variabel kinerja guru SMK Muhammadiyah 1 Prambanan Klaten pada kategori kurang optimal. Dan penelitian (Djafar \& Nurhafizah, 2018) dengan hasil penelitian bahwa kinerja guru dan pegawai di SMK Muhammadiyah 3 Makassar berada pada kategori sedang yakni $95 \%$.

Hubungan motivasi kerja dengan kinerja guru di MTs Mohamad Toha Kota Cimahi, diperoleh nilai Koefisien Determinasi sebesar 78,85\% yang menunjukkan arti bahwa variabel motivasi kerja memberikan kontribusi terhadap variabel kinerja guru sebesar $78,85 \%$. Sedangkan sisanya sebesar $21,15 \%$ dipengaruhi oleh faktor lain yang diabaikan penulis. Hal ini sesuai dengan penelitian (Laily \& Darsinah, 2018) yang menyatakan terdapat hubungan yang kuat antara motivasi kerja dengan kinerja guru TK se-Kecamatan Colomadu tahun 2018, berdasarkan hasil regresi linier terdapat sumbangan sebesar $51,2 \%$, maka motvasi kerja memiliki kontribusi terhadap kinerja guru sebesar 51,2\%. Motivasi kerja memberikan dorongan terhadap para guru agar kinerja guru yang dihasilkan dapat lebih maksimal. Penelitian lainnya yaitu penelitian (Fredianto, 2016) menunjukkan bahwa terdapat hubungan yang signifikan dan positif antara motivasi kerjadan kedisiplinan dengan kinerja guru. Penelitian (Ardiana, 2017) hasilnya menunjukan adanya hubungan motivasi kerja terhadap kinerja guru akuntasi secara positif dengan sumbangan sebesar $80,6 \%$, sisanya sebesar $19,4 \%$ yang dilatarbelakangi oleh faktor lain. Penelitian (Dewi, 2012), hasilnya menunjukan terdapat motivasi kerja terhadapa kinerja guru honorer secara signifikan dan berpengaruh positif. Penelitian (Mariza, 2011) diperoleh nilai " $r$ " (Pearson Correlation) sebesar 0.981 dengan tingkat probabilitas 0,000 . Oleh karena probabilitas lebih kecil dari 0,05 maka Ho ditolak dan Ha yang artinya ada hubungan yang signifikan antara motivasi kerja dan kinerja guru di SMK Muhammadiyah 2 Pekanbaru. Hal ini menunjukkan bahwa adanya kesamaan dengan penelitian sebelumnya yang menyatakan bahwa adanya hubungan secara signifikan dan positif antara motivasi kerja dengan kinerja guru. 
Motivasi kerja dan kinerja guru madrasah serta implikasinya bagi Manajemen Pendidikan Islam adalah proses pemanfaatan semua sumber daya yang dimiliki (umat Islam, lembaga pendidikan atau lainnya) baik perangkat keras maupun lunak. Dalam penelitian (Seputri, 2016), pemanfaatan tersebut dilakukan melalui kerjasama dengan orang lain secara efektif, efisien, dan produktif untuk mencapai kebahagiaan dan kesejahteraan baik di dunia maupun di akhirat. Sehingga dalam pemanfaatan tersebut peran motivasi yang tinggi sangat diperlukan agar mampu menghasilkan kinerja yang optimal serta tercapai tujuan yang efektif dan efisien.

\section{SIMPULAN}

Berdasarkan hasil penelitian secara umum mengenai variabel motivasi kerja guru di MTs Mohamad Toha Kota Cimahi menunjukkan bahwa keseluruhan jawaban responden pada variabel motivasi dengan persentase sebesar $72,58 \%$ dan termasuk kategori yang tinggi. Sedangkan mengenai variabel kinerja guru di MTs Mohamad Toha Kota Cimahi, berdasarkan hasil pengolahan data menunjukkan bahwa keseluruhan jawaban responden persentasenya sebesar $74,21 \%$ juga termasuk kategori yang tinggi. Dengan demikian bahwa baik motivasi kerja maupun kinerja guru di MTs Mohamad Toha Kota Cimahi termasuk dalam kualifikasi yang tinggi.

Hubungan antara motivasi kerja guru dengan kinerja guru di MTs Mohamad Toha Kota Cimahi, terdapat hubungan sebesar 0,888. Artinya tingkat kekuatan hubungan antara variabel motivasi kerja dengan kinerja guru di MTs Mohamad Toha Kota Cimahi termasuk kategori yang sangat kuat. Dengan demikian dapat disimpulkan bahwa Ha diterima, hal ini memberikan arti bahwa ada hubungan yang positif dan signifikan antara motivasi kerja dengan kinerja guru di MTs Mohamad Toha Kota Cimahi.

\section{REFERENSI}

Amaliah, I., Julia, A., \& Riani, W. (2013). Pengaruh dari Nilai-Nilai Islam terhadap Kinerja Kerja. MIMBAR, Jurnal Sosial Dan Pembangunan, 29(2), 165-174. https://doi.org/10.29313/mimbar.v29i2.394

Ardiana, T. E. (2017). Pengaruh Motivasi Kerja Guru Terhadap Kinerja Guru Akuntansi SMK Di Kota Madiun. Jurnal Akuntansi Dan Pajak, 17(02), 14-23. https://doi.org/10.29040/jap.v17i02.11

Daryanto, D., \& Farid, M. (2013). Konsep Dasar Manajemen Pendidikan di Sekolah. Gava Media.

Dewi, C. A. (2012). Pengaruh Motivasi Kerja Terhadap Kinerja Guru Honorer (Studi Kasus Guru Honorer SMAN Rumpun IPS se-Kecamatan Temanggung).

Djafar, H., \& Nurhafizah, N. (2018). Pengaruh Motivasi Kepala Sekolah Terhadap Kinerja Guru Dan Pegawai Di SMK Muhammadiyah 3 Makassar. Idaarah: Jurnal Manajemen Pendidikan, 2(1), 24-36. https://doi.org/10.24252/idaarah.v2i1.5064

Fredianto, D. (2016). Hubungan antara Motivasi Kerja dan Kedisiplin dengan Kinerja Guru di SD. Jurnal Manajer Pendidikan, 10(4), 354-361. https://garuda.ristekbrin.go.id/documents/detail/755702

Hidayat, R., \& Wijaya, C. (2017). Ayat-Ayat Al-Quran Tentang Manajemen 
Pendidikan Islam. Lembaga Peduli Pengembangan Pendidikan Indonesia. Laily, I., \& Darsinah, D. (2018). Hubungan Motivasi Kerja Terhadap Konerja Guru TK se-Kecamatan Colomadu Tahun 2018. http://eprints.ums.ac.id/64916/ Mangkunegara, A. P. (2019). Evaluasi Kinerja SDM. Refika Aditama.

Mariza, L. (2011). Hubungan Antara Motivasi Kerja Dengan Kinerja Guru di SMK Muhammadiyah 2 Pekanbaru. http://repository.uin-suska.ac.id/520/

Mulyasa, E. (2004). Manajemen Berbasis Sekolah (Konsep, Strategi, dan Implementasi). Remaja Rosda Karya.

Munirah, M. (2015). Sistem Pendidikan di Indonesia: Antara Keinginan dan Realita. Auladuna: Jurnal Pendidikan Dasar Islam, 2(2), 233-245. http://journal.uin-alauddin.ac.id/index.php/auladuna/article/view/879

Putra, M. H., \& Wikansari, R. (2017). Pengaruh Motivasi Terhadap Prestasi Kerja Karyawan. JAMEB: Jurnal Aplikasi Manajemen, Ekonomi Dan Bisnis, 1(2), 65-78. http://www.jameb.stimlasharanjaya.ac.id/JAMEB/article/view/25

Sahertian, P. A. (2010). Konsep Dasar dan Teknik Supervisi Pendidikan (Dalam Rangka Pengembangan Sumber Daya Manusia). Rineka Cipta.

Samsirin, S. (2016). Konsep Motivasi Personalia Dalam Manajemen Pendidikan Islam. At Ta'dib: Journal of Pesantren Education, 11(1), 89-108. https://doi.org/10.21111/at-tadib.v11i1.637

Saoetarno, S. (2004). Sumber Daya Pendidikan dengan Pendekatan Sistem. UMS.

Seputri, S. (2016). Konsep Manajemen Pendidikan Islam: Sebuah Analisis Aspek Ontologi, Epistemologi, dan Aksiologi Konsep Manajemen Pendidikan Islam. Al-Idarah: Jurnal Manajemen Dan Administrasi Islam2, 6(1), 62-93. https://doi.org/10.24042/alidarah.v6i1.790

Siregar, S. (2015). Metode Penelitian Kuantitatif (Dilengkapi dengan Perbandingan Perhitungan Manual dan SPSS). Prenada Media Grup.

Sonedi, S., Sholihah, T., \& Dihasbi, D. (2018). Peran Kepemimpinan Kepala Sekolah Dalam Meningkatkan Kinerja Guru (The Role of Principal Leadership in Improving Teacher Performance). Anterior Jurnal, 18(1), 1322. https://doi.org/10.33084/anterior.v18i1.436

Sudjana, S. (2011). Statistika untuk Ekonomi dan Niaga. PT Tarsito.

Sugiyono. (2017). Metode Penelitian Kuantitatif, Kualitatif dan R\&D. Alfabeta.

Tentama, F. (2015). Peran Kepuasan Kerja Terhadap Kinerja Pada Guru Pegawai Negeri Sipil (PNS) di Yogyakarta. Jurnal Psikologi Universitas Diponegoro, 14(1), 1-8. https://doi.org/10.14710/jpu.14.1.1-8

Yulia, L. (2017). Pengaruh Motivasi Kerja Guru dan Kompetensi Pedagogik Terhadap Kinerja Guru SMK Muhammadiyah 1 Prambanan Klaten. https://eprints.uny.ac.id/53734/ 